\title{
Translation Analysis on Civil Engineering Text Produced by Machine Translator
}

\author{
Anam Sutopo, \\ Department of English Education, Faculty of Teacher Training and Education, Universitas Muhammadiyah Surakarta - Indonesia
}

\begin{abstract}
Translation is extremely needed in communication since people have serious problem in the language used. Translation activity is done by the person in charge for trans lating the material. Translation activity is also able to be done by machine. It is called machine translation, reflected in the programs developed by programmer. One of them is Transtool. Many people used Transtool for helping them in solving the problem related with translation activities. This paper wants to deliver how important is the Transtool program, how effective is Transtool program and how is the function of Transtool for human business. This study applies qualitative research. The sources of data were document and informant. This study used documentation and in dept-interviewing as the techniques for collecting data. The collected data were analyzed by using interactive analys is. The results of the study show that, first; Transtool program is helpful for people in translating the civil engineering text and it functions as the aid or helper, second; the working of Transtool software program is effective enough and third; the result of translation produced by Transtool is good for short and simple sentences and not readable, not understandable and not accurate for long sentences (compound, complex and compound complex) thought the result is informative. The trans lated material must be edited by the professional trans lator.
\end{abstract}

\section{Introduction}

Discussing translation means talking about communication. It is due to the fact that between translation and communication has the same focus, namely: message. The message or meaning is extremely important for communication and translation. Therefore, without considering meaning translation is nothing. A good translation result may be stated as a nice communication.

Translation activities have a great role in developing science and technology. The development of science and technology is only depending on the natural resource that from time to time has been reduced, but also influenced by the quality of human resources. There are many ways to improve the quality of human resources. One of them is by increasing their ability in understanding of the recent knowledge and technology. Meanwhile, it cannot be denied that most of the available books, relevant with knowledge and technology are written in English. There are $75 \%$ of the available books, which are collected by Indonesian library, are written in English and there is only $5 \%$ of the readers who understand them [1]. It means that the coming of translation becomes an alternative solution. In other words, we may say that translation can be a bridge in transferring the message from English to Indonesian. By translating books, readers who do not understand English can read and get the knowledge that they want.

Translation is not an easy task. It needs a serious attention and concentration. It is due to the fact that the core of translation is transferring 'meaning' (message). The translator must be careful in replacing meaning from source to target language [2]. It is also hard forbidden for translator to gain or loss the messages. The translator should be able to look for the closest meaning from source to target language. The translator must keep the excess and mission in the source language then transfer them to target one. If the translator is able to translate well semantically but he cannot move the closest mission, the result of translation is useless. The translator spends his time and energy carelessly. Therefore, to avoid this useless activity and to have a good work, the translator should master not only linguistics aspect and but also the materials that will be translated as well as the theory of translation [3].

There is nice phenomenon in translation result done by machine translator [4]. One of them is translation which is done using Transtool program.

Corresponding author: anam.sutopo@ums.ac.id 
This program has been used by many people. The following is the example of translation done by this program:

\section{SL : Over the past two decades concrete has enjoyed a renewed level of research and testing, resulting in the development of many new types of concrete. \\ $T L$ : (Di) atas masa lalu dua dekade beton telah menikmati suatu [yang] diperbaharui tingkat riset dan pengujian, menghasilkan pengembangan dari banyak jenis baru beton .}

From the TL, it can be seen that the result translation done by Transtool above is not readable. It means that the language used is not easy to read and the content is difficult to understand. There are too many choices in the bracket and difficult to understand.

There are many definitions of translation. In analyzing translation, there are two languages involved in translation, they are the source language and the target language. Larson argues that translation is basically a change of form. When we speak of a language, we are referring to the actual words, phrases, clauses, sentences, paragraphs, et., which are spoken or written. These forms are referred to as the surface structure of a language[5]. She also says that the form which the translation is made will be called the source language and the form into which it is to be changed will be called the receptor language. Ttranslation is an operation performed on language: a process of substituting a text in one language for a text in other [6]. From those definition it can be drawn conclusion that translation as a process of replacing language and culture content from a Source Language into a Target Language.

There are two kind of translation, they are; form-based translation and meaning-based translation [7]. Literal translation is called as form-based translation. The literal translation is the form of the source language that transferred into the form of target language. Although the literal translation is useful for the purposes of the related study of the source language, it can help the speakers of target language who are interested for the meaning of the source language. The literal translation gives priority of form whether in words, clause or sentences make the result of the translation sound unnatural and has a little value of communication. The result of translation text becomes bad translation because the translator makes the use the words with the contextual meaning.

According to Jumpelt, there are three major steps when the process of translation happens[8]. First, the translator needs to discover the meaning of the message in the source language to be translated. Second is the process of determining of the meaning to gets related meaning for communicated the message in the target language. The last, the translators need to write or re-express the meaning or the message with the context in the target language using the translation equivalent.

The equivalence of the translation is very important things in transferring one language into other languages, getting relation between the source language and the target language. Nababan states equivalence of translation have some conditions translation equivalence occurs when a SL and a TL text are relatable to (at least some of) the same features of substance [9]. Based on the statement, it has meaning that when source language has some language relations for the relations for the features of substance with the target language, is possible for the translation equivalence to occurs. The translation cannot be based only for some meanings but it must be related to the some situations and contexts where the equivalence should be established. There are three aspects of the quality of the translation; they are readability, accuracy and acceptability of the translation [10]. Readability in translation is about how easily written materials can be read and understood. Readability is what makes some texts easier to read by readers. To maximize readability is a goal that every writer, technical or otherwise, should strive to achieve. Readability has two common meanings, one applying to document design, the other to language. Readability as it is applied to document design is concerned with such matters as line length, leading, white space, font type and the like. Readability as it is applied to language is concerned with the comprehensibility or understandability of a piece of written text. Readability level is about some standards criteria to get the readability score of a text. Readability level must be divided into several levels with different score of each.

The accuracy of translation is an important part of translation [11]. Accuracy is one of the factors which are used to determine the quality of translation. Accuracy also means that the meaning of the source text is transferred in the target text correctly. Basically, accuracy is related to choose the correct words in order to reveal the same idea in target language. Choosing the right word is very important because if the translators incorrectly choose the word, the text will not be accurate. Choosing the right word should consider some factors, such as the target readers, context of the text and the socio - cultural condition. Acceptability refers to how the translation product can be accepted by the readers [12]. The target text must be intended to be a text and accepted as such in order to be utilized in communicative interaction. Acceptability is a term firstly used the translator referring to a targettext-oriented approach to translation [13]. He concludes that a translation is assumed to be acceptable if it fulfills the requirements of 'reading as an original' written in the target language and sound natural for the target reader rather than that of 'reading as the original' in source language. The acceptability of translation is determined by the faithfulness to the linguistic and literary norms of target system [14]

Meanwhile, linguistics Unit is the one of the natural units into which linguistic messages can be analyzed. In English grammar we have five part of linguistics unit from the larger units being made up of smaller units. They form a scale of units at different ranks, also called as rank scale. We have five units; morpheme, word, phrase, clause, and sentence. The 
largest or highest on the rank scale is the sentence and the smallest on the rank scale is the morpheme.

Besides explanation on English grammatical/ linguistics unit, Indonesia grammatical needed to be explained as well. Actually there is bo difference between English and Indonesia linguistics unit. Indonesia also have five units of linguistic, morfem (morpheme), kata (word), frasa (phrase), klausa (clause) and kalimat (sentence) and this is the linguistics unit from English and Indonesia.

Sentence is a grammatically complete construction, it does not need the help of other construction to make its grammatical meaning clearer. Pym states that a sentence is an independent linguistic form, not included by virtue of any grammatical construction in any longer linguistic form[15]. According to its structure, sentence is divided into three classes, they are simple sentence, compound and complex sentences.

Simple sentence is the sentence that contains only one subject and one predicate, in other word the simple sentence contains no clauses. Compound sentence is a sentence containing more than one predication; the over-all construction is a coordination of two or more simple sentences. It means that two or more simple sentences (independent clauses) can be combined to form a compound sentence, frequently using coordinating conjunction[16]. Complex sentence is a sentence containing more than one predication, one of the predications is some kind of subordinate element - a modifier, a subject, or complement.

\section{Research Method}

The type of this study belongs to descriptive qualitative study. The aims of this research to know the function of Transtool program, to show how this program works and to describe the result of translation civil engineering text done by this program. The writer uses document (civil Engineering texts) and informant as the source of data while the techniques for collecting data used by the writer are documentation and interview. The researcher has following the procedures for this research, as follows: comparing the data between the source language and the target language, classifying them and then justifying the quality of the translation. To check the validity of data, the writer uses data and method triangulations. Then, he collected data are analyzed by using Interactive Analysis as seen in the following diagram:

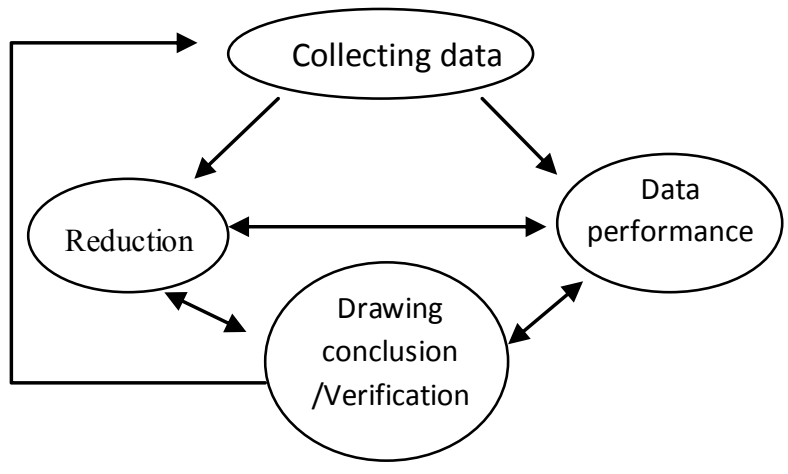

\section{Result and Discussion 3.1 Helpful}

Based on the collected information given by the informants, Transtool program is very helpful. This software can help many them in translating the civil Engineering text from English to Indonesian and from Indonesian to English. Most of them felt that Transtool program is always ready helping them in transferring the meaning from Indonesian to English.

At least, it was expressed by informant W. He said that when he wrote an article as the assignment from his lecturer in post graduate program, he got problem with reference. The solution is using Transtool program to translate the collected material by using Transtool software. He could find the main information from the translated material done by the Transtool program.

The same expression said by informants. She used Transtool program when she wrote not only article but also theses. As we know that writing theses is not easy. It needs some references and most of articles and references were written in English she said. She had no choice. If she wanted to hire translator, she would spend much money and time. Not all the result of translation was useful to completing writing her theses. The only Transtool program that helped her in finding some references. The similar argument also given by informant $\mathrm{N}$ and $\mathrm{B}$.

After crosschecking the implementation of Transtool program as software, the writer may conclude that the Software of Transtool is helpful. It can support the everyone who has problem dealing with translation working. It may help them to change the language used from Indonesia to English and from English to Indonesian. It means, the writer concludes that the Transtool program is helpful for translating the Civil Engineering texts.

\subsection{Effectiveness}

In line with the effectiveness of this software, informant $\mathrm{S}$ said that as the Transtool program is effective enough seen from the time needed. The fact shows that Transtool program can help him in translating many pages of the text in short time. He just needed the time for copying and pasting. Copying the source language then transferring by Transtool program and finally pasting the result of translation into the new file.

This step is also done by other informants. They have similar argument that as the aid Transtool program just needs a few minutes for doing this translation work. From the consolidated information or statement above it can be concluded that the effectiveness of Transtool program is effective enough as the aid. It is as the helper to translate the provided articles.

\subsection{Accuracy and Readability.}

Although the Transtool program is useful and effective enough as the aid for translating the civil Engineering text both from English to Indonesian or 
the opposite one, the result of translation produced by this software is questionable. Even, the translation result produced by this program is broken. At least, it can be seen from the readability aspect. Yes, this machine translator can transferred the meaning from Bsu to Bsa quickly. It just needs a short time to do translation or to change the message from English to Indonesian.

Anyhow, when it is seen from the quality of result (readability), the Transtool program cannot do it well. The result of this software is broken, not good. Let's see the following example:

SL : Civil engineering is the term for the work of designing and building infrastructure.

TL : Rancang-Bangun sipil adalah istilah untuk pekerjaan merancang dan membangun infrastruktur.

This datum is belonging to simple or short sentence. From this datum it can be seen that the Trandtool program can change or transfer the meaning from SL to TL successfully. The phrase 'civil engineering ' is transferred into 'rancang-bangun cipil'. The phrase of 'in term of' is translated into 'istilah' and the phrase of 'building infrastructure' is translated into 'membangun infrastruktur'.

So, this translated sentence is easily to read the meaning is easy to understand, therefore this datum includes into the high readability level. In this case the writer concludes that the source language translated into the target language well and can be understood by the reader. This translation can be stated accurate because the machine translator has translate into the target language correctly.

\section{SL : Civil engineering has many different areas or disciplines. \\ TL : Rancang-Bangun sipil mempunyai banyak area berbeda atau disiplin.}

This datum is belonging to simple or short sentence. From this datum it can be seen that the Trandtool program can change or transfer the meaning from SL to TL successfully. The phrase 'civil engineering ' is transferred into 'rancang-bangun cipil'. The phrase of 'different areas' is translated into 'area berbeda' and the phrase of 'disciplines' is translated into 'disiplin.

So, this translated sentence is easily to read the meaning is easy to understand, therefore this datum includes into the high readability level. In this case the writer concludes that the source language translated into the target language well and can be understood by the reader. This translation can be stated accurate because the machine translator has translate into the target language correctly.

SL : Chartership shows employers and clients that they are both qualified and experienced in their jobs.

TL : Pencarteran menunjukkan pemberi kerja dan klien yang mereka adalah kedua-duanya [yang]

\section{berpengalaman dan berkwalitas di (dalam) pekerjaan mereka.}

In this case the writer classifies that this datum belonging to medium readability level because the translator no needed to rewriting some words from source language to translates into the target language. Medium readability occurs if the translation makes the readers need to read more than one to catch the meaning. For example, it can be happened when the source language translated into the target language well and can be understood by the reader. It indicates that the phrase 'both qualified and experienced' which is translated into 'kedua-duanya [yang] berpengalaman dan berkwalitas' and the phrase 'in their jobs' which is translated into 'di (dalam) pekerjaan mereka'.

This data also belongs to less accurate because the meaning or message from the source language and target language less inaccurate. Translation can be less accurate because the Transtool machine translator translates the word 'chartership' into 'pencarteran'. So, this translation categories into less accurately.

SL : Structural engineering is a subset of civil engineering dealing with the design and analysis of buildings and large non-building structures to withstand both the gravity and wind loads as well as natural disasters. Besides, it may also cover design of machinery, medical equipment, vehicles or any other objects where structural functionality or safety are involved. Structural engineers must ensure their designs satisfy building codes.

TL : Rancang-Bangun struktural adalah suatu subset tehnik sipil berhadapan dengan disain dan analisa bangunan dan struktur tidak membangun besar ke withstand kedua-duanya gaya berat dan memutar beban seperti halnya bencana alami. Di samping, mungkin juga [meliput/tutup] perancangan permesinan, peralatan kedokteran, sarana (angkut) atau object lain [di mana/jika] keselamatan atau kemampuan struktural dilibatkan. Insinyur struktural harus memastikan disain mereka mencukupi membangun kode.

This datum belonging to not readability and not accurate. It is due to the fact that the target language 'Rancang-Bangun struktural adalah suatu subset tehnik sipil berhadapan dengan disain dan analisa bangunan dan struktur tidak membangun besar ke withstand kedua-duanya gaya berat dan memutar beban seperti halnya bencana alami. Di samping, mungkin juga [meliput/tutup] perancangan permesinan, peralatan kedokteran, sarana (angkut) atau object lain [di mana/jika] keselamatan atau kemampuan struktural dilibatkan. Insinyur struktural harus memastikan disain mereka mencukupi membangun kode' cannot be read easily and difficult understand. The readers cannot read this $\mathrm{BSa}$ successfully. The content is also not accurate. There is different meaning between SL and TL. This data belongs to not accurate because the meaning or 
message from the source language and target language is different.

SL : Entry-level structural engineers may design individual structural elements of a structure, for example, beams, columns, and floors of a building. More experienced engineers would be responsible for the structural design and integrity of an entire system, such as a building.

TL : Entry-Level insinyur struktural boleh mendisain unsur-unsur [yang] struktural individu suatu struktur, sebagai contoh, [balok/berkas cahaya], kolom, dan lantai suatu bangunan. Insinyur [yang] lebih berpengalaman akan bersifat bertanggung jawab untuk integritas dan disain yang struktural dari suatu keseluruhan sistem, seperti suatu membangun.

This datum belongs to not readability and not accurate. It is due to the fact that the target language 'EntryLevel insinyur struktural boleh mendisain unsur-unsur [yang] struktural individu suatu struktur, sebagai contoh, [balok/berkas cahaya], kolom, dan lantai suatu bangunan. Insinyur [yang] lebih berpengalaman akan bersifat bertanggung jawab untuk integritas dan disain yang struktural dari suatu keseluruhan sistem, seperti suatu membangun' cannot be read easily and difficult understand. The readers cannot read this BSa successfully. The content is also not accurate. There is different meaning between SL and TL. This data belongs to not accurate because the meaning or message from the source language and target language is different.

\section{Conclusion}

Translation is not an easy task. It needs a serious attention and concentration. Translation is the process of transferring meaning or message from source into target language. There are three steps in translation process, namely (1) analyzing, (2) transferring and (3) restructuring. Translation can be done by the machine translator. One of them is Transtool software program. This study recommends that Transtool is a helpful software. It can support the everyone who has problem dealing with translation working. It may help them to change the language used from Indonesia to English and from English to Indonesian. It means, the writer concludes that the Transtool program is helpful for translating the Civil Engineering texts. The Transtool program is effective enough as the aid. The Transtool program helps people to translate the text in short time. It is for copying they material to be translated to the machine and pasting the result of translation to another program. It means that copying the source language then transferring by Transtool program and finally pasting the result of translation into the new file. Dealing with Quality of translation seen from readability and accuracy, for the simple sentences text the translated material is easy to read and understandable. For the long sentences (complex and compound complex) result of translation is not readable (the readability is low), not understandable and not accurate although the result above is informative.

\section{References}

1. Sadtono, F. Pedoman Penerjemahan. 141 (1985).

2. Miyanda, Fewdays. Total Meaning and Equivalence in Translation. NAWA Journal of Language and Communication. 56 (2007)

3. Sang, Jian dan Zhang, Grace. Communication across languages and cultures: A perspective of brand name translation from English to Chinese. Journal of Asian Pacific Communication ISSN 0957-6851/E-ISSN 1569-9838. 246. (2008)

4. Hui-juan, Ma. Exploring the differences between Jin Di's translation theory and Eugene A. Nida's translation theory. The Journal of Babel. ISSN 0521-9744/E-ISSN 1569-9668. 99. (2007)

5. Larson, M. Meaning Based Translation, A Guide to Cross-Language Equivalent. 15. (1991)

6. Catford, J.C. A Linguistic Theory of Translation. 156. (1974.)

7. Hui-juan, Ma. (2007). Exploring the differences between Jin Di's translation theory and Eugene A. Nida's translation theory. The Journal of Babel. issn 0521-9744/e-issn 1569-9668. 101 (2007)

8. Jumpelt, B. The Science of Translation. 67. (1981)

9. Nababan M R. Aspek Teori Penerjemahan dan Pengalihbahasaan. Surakarta : PPS-UNS (1997)

10. Sutopo, Anam. Terjemahan dan Penerjemahan: Kajian Lintas Pemahaman. 17. (2014)

11. Sutopo, Anam. (2015). Penerjemahan Naskah Resmi: Telaah Holistik Pidato Kenegaraan. Solo: MUP Press UMS.

12. Newmark, P. A Textbook of Translation. 42 (1987)

13. Nida, E A. Commponental Analysis of Meaning. An Introduction to Semantic Structures. 78 (2008)

14. Ordudary, M. Translation Procedures, Strategy and Methods. Translation Journal. Volume 11, No 3, July 2007. 265 (2007).

15. Pym, Anthony. Natural and directional equivalence in theories of Translation .Target Volume 19 Issue 2. ISSN 0924-1884 / E-ISSN 1569-9986. 284 (2007).

16. Miyanda, Fewdays. Total Meaning and Equivalence in Translation. NAWA Journal of Language and Communication, . Volume 11, No 3, June 2007. (2007) 